Marquette University

e-Publications@Marquette

College of Nursing Faculty Research and

Publications

Nursing, College of

$7-2015$

\title{
Emerging Areas of Science: Recommendations for Nursing Science Education from the Council for the Advancement of Nursing Science Idea Festival
}

\author{
Susan J. Henly \\ University of Minnesota \\ Donna O. McCarthy \\ Marquette University, donnalee.mccarthy@marquette.edu \\ Jean F. Wyman \\ University of Minnesota \\ Margaret M. Heitkemper \\ University of Washington \\ Nancy S. Redeker \\ Yale University
}

See next page for additional authors

Follow this and additional works at: https://epublications.marquette.edu/nursing_fac

Part of the Nursing Commons

\section{Recommended Citation}

Henly, Susan J.; McCarthy, Donna O.; Wyman, Jean F.; Heitkemper, Margaret M.; Redeker, Nancy S.; Titler, Marita; McCarthy, Ann Marie; Stone, Patricia W.; Moore, Shirley M.; Alt-White, Anna C.; and Conley, Yvette P., "Emerging Areas of Science: Recommendations for Nursing Science Education from the Council for the Advancement of Nursing Science Idea Festival" (2015). College of Nursing Faculty Research and Publications. 420.

https://epublications.marquette.edu/nursing_fac/420 


\section{Authors}

Susan J. Henly, Donna O. McCarthy, Jean F. Wyman, Margaret M. Heitkemper, Nancy S. Redeker, Marita Titler, Ann Marie McCarthy, Patricia W. Stone, Shirley M. Moore, Anna C. Alt-White, and Yvette P. Conley 


\title{
Emerging Areas of Science: Recommendations for Nursing Science Education from The Council for The Advancement of Nursing Science Idea Festival
}

\author{
Susan J. Henly \\ School of Nursing, University of Minnesota, \\ Minneapolis, MN \\ Donna O. McCarthy \\ School of Nursing, Marquette University \\ Milwaukee, WI \\ Jean F. Wyman \\ School of Nursing, University of Minnesota, \\ Minneapolis, $M N$ \\ Margaret M. Heitkemper \\ School of Nursing, University of Washington, \\ Seattle, WA \\ Nancy S. Redeker \\ School of Nursing, Yale University, \\ West Haven, CT \\ Marita G. Titler \\ School of Nursing, University of Michigan,
}

Nursing Outlook, Vol 63, No. 4 (July-August, 2015): pg. 398-407. DOI. This article is @ Elsevier and permission has been granted for this version to appear in e-Publications@Marquette. Elsevier does not grant permission for this article to be further copied/distributed or hosted elsewhere without the express permission from Elsevier. 


\author{
Ann Arbor, MI \\ Ann Marie McCarthy \\ College of Nursing, University of Iowa, \\ Iowa City, IA \\ Patricia W. Stone \\ School of Nursing, Columbia University, \\ New York, NY \\ Shirley M. Moore \\ Frances Payne Bolton School of Nursing, \\ Case Western Reserve University, \\ Cleveland, $\mathrm{OH}$ \\ Anna C. Alt-White \\ Office of Nursing Services, U.S. Department of Veterans Affairs, \\ Washington, $D C$ \\ Yvette P. Conley \\ School of Nursing, University of Pittsburgh, \\ Pittsburgh, PA \\ Jacqueline Dunbar-Jacob \\ School of Nursing, University of Pittsburgh, \\ Pittsburgh, PA
}

\begin{abstract}
The Council for the Advancement of Nursing Science aims to "facilitate and recognize life-long nursing science career development" as an important part of its mission. In light of fast-paced advances in science and technology that are inspiring new questions and methods of investigation in the health sciences, the Council for the Advancement of Nursing Science convened the Idea Festival for Nursing Science Education and appointed the Idea Festival Advisory Committee (IFAC) to stimulate dialogue about linking $\mathrm{PhD}$ education with a renewed vision for preparation of the next generation of nursing scientists. Building on the 2005 National Research Council report Advancing The Nation's Health Needs and the 2010 American Association of Colleges of Nursing Position Statement on the Research-Focused Doctorate Pathways to Excellence, the IFAC specifically addressed the capacity of PhD programs to prepare nursing scientists to conduct cutting-edge research in the following key emerging and priority areas of health sciences research:
\end{abstract}

Nursing Outlook, Vol 63, No. 4 (July-August, 2015): pg. 398-407. DOI. This article is @ Elsevier and permission has been granted for this version to appear in e-Publications@Marquette. Elsevier does not grant permission for this article to be further copied/distributed or hosted elsewhere without the express permission from Elsevier. 
omics and the microbiome; health behavior, behavior change, and biobehavioral science; patient-reported outcomes; big data, e-science, and informatics; quantitative sciences; translation science; and health economics. The purpose of this article is to (a) describe IFAC activities, (b) summarize 2014 discussions hosted as part of the Idea Festival, and (c) present IFAC recommendations for incorporating these emerging areas of science and technology into research-focused doctoral programs committed to preparing graduates for lifelong, competitive careers in nursing science. The recommendations address clearer articulation of program focus areas; inclusion of foundational knowledge in emerging areas of science in core courses on nursing science and research methods; faculty composition; prerequisite student knowledge and skills; and in-depth, interdisciplinary training in supporting area of science content and methods.

Keywords: Nursing research, Nursing science, Research-focused doctorate, Nursing scientist training, Research-focused doctorate

Nursing science is the science of health (Donaldson, 2003a). Nursing science concerns the "conditions necessary and sufficient for the promotion, maintenance, and restoration of health in human beings" (Donaldson, 2003a and Donaldson and Crowley, 1978). Nursing research addresses the health and illness experiences of individuals, families, and communities in context over time; nursing interventions and outcomes; mechanisms of health and illness; nursing systems and quality of care; and translation science, health policy, and economics related to nursing practice and nursing care outcomes (Henly et al., 2015). Nursing science overlaps with the biological, behavioral, and social sciences at levels from molecules to societies considered in context and over time (Diez-Roux, 2007 and Glass and McAtee, 2006; National Institute of Nursing Research National Institute of Nursing Research, 2011 and Wyman and Henly, 2011). Thus, interdisciplinary perspectives on health and health care have long been valued in nursing science (American Association of Colleges of Nursing American Association of Colleges of Nursing, 2006, Carper, 1978, Donaldson and Crowley, 1978 and Stevenson and Woods, 1986).

Rapidly developing advances in the life sciences and technology (American Association of Colleges of Nursing, 2010, Henly, 2013 and Henly et al., 2015) are stimulating nursing scientists to consider how the science and methods of other disciplines can inform nursing science and how nursing science can inform these related fields. In nursing, now more than ever, PhD education must also 
prepare nursing scientists to lead and participate in interdisciplinary team science to address complex issues that affect health and the delivery of health care (Begg et al., 2014, Bennett and Gadlin, 2012, Grey and Mitchell, 2008 and Kneipp et al., 2014). Addressing these issues requires that the education of the next generation of nursing scientists be qualitatively different from the past in science content, methods of science, and research training.

\section{The CANS Idea Festival for Nursing Science Education}

The CANS Idea Festival for Nursing Science Education was proposed as an advisory committee of creative experts in nursing science charged with crafting the provocative questions needed to stimulate dialogue about linking PhD education with emerging and priority areas of science impacting preparation of the next generation of nursing scientists. The CANS Idea Festival Advisory Committee (IFAC) was asked to (a) pose the questions for dynamic and vigorous dialog about the content essential to preparing PhD students for the future of nursing science; (b) design a time line and forums for generation, dissemination, and evaluation of ideas; and (c) create an action plan for the transformation of nursing science education incorporating emerging areas of science and technology needed to prepare PhD students to launch and sustain competitive careers as nursing scientists.

\section{Composition}

Members of the IFAC are listed in Table 1. Expertise of the members ranged from bench science and biobehavioral research to translational research and health economics. Most were senior members of faculties of schools of nursing or deans; researchers from practice were also represented. Dr. Yvonne Bryan served as the liaison from the NINR.

Nursing Outlook, Vol 63, No. 4 (July-August, 2015): pg. 398-407. DOI. This article is @ Elsevier and permission has been granted for this version to appear in e-Publications@Marquette. Elsevier does not grant permission for this article to be further copied/distributed or hosted elsewhere without the express permission from Elsevier. 
NOT THE PUBLISHED VERSION; this is the author's final, peer-reviewed manuscript. The published version may be accessed by following the link in the citation at the bottom of the page.

Table 1. Idea Festival Advisory Committee Roster

\author{
Susan J. Henly, PhD, RN, FAAN (Chair, \\ CANS-IF) \\ University of Minnesota \\ henly003@umn.edu \\ Jerilyn Allen, ScD, RN, FAAN \\ Johns Hopkins University \\ jallen1@jhu.edu \\ Yvette Conley, PhD \\ University of Pittsburgh \\ yconley@pitt.edu \\ Margaret Heitkemper, PhD, RN, FAAN \\ University of Washington \\ heit@u.washington.edu \\ Donna McCarthy, PhD, RN, FAAN \\ Marquette University \\ donnalee.mccarthy@marquette.edu \\ Suzanne S. Prevost, PhD, RN, COI \\ University of Alabama \\ sprevost@ua.edu \\ Marita Titler, PhD, RN, FAAN \\ University of Michigan \\ mtitler@umich.edu \\ Patricia Stone, PhD, RN, FAAN \\ Columbia University \\ ps2024@columbia.edu
}

\author{
Jean F. Wyman, PhD, RN, FAAN (Chair, \\ CANS Steering Committee) \\ University of Minnesota \\ wyman002@umn.edu
}

Yvonne Bryan, PhD (NINR Liaison)

yvonne.bryan@nih.gov

Jacqueline Dunbar-Jacob, PhD, RN, FAAN

University of Pittsburgh

dunbar@pitt.edu

Ann Marie McCarthy, RN, PhD, FAAN

University of Iowa

ann-mccarthy@uiowa.edu

Shirley Moore, PhD, RN, FAAN

Case Western Reserve University

smm8@case.edu

Nancy Redeker, PhD, RN, FAHA, FAAN

Yale University

nancy.redeker@yale.edu

Anna Alt-White, PhD, RN, FAAN

US Department of Veterans Affairs

anna.alt-white@va.gov

Laura Smothers, MPA (CANS Support)

Laura_Smothers@AANnet.org

\section{Activities}

\section{Initial Meeting}

The IFAC first met at the 2012 CANS State of the Science Conference where the Idea Festival for Nursing Science Education was discussed fully. Members present at this first meeting agreed on the following emerging or priority areas of science that were likely to impact the ability of the PhD graduates to conduct competitive nursing research in the future: (a) omics and the microbiome; (b) patientreported outcomes; (c) health behavior, behavior change, and biobehavioral science; (d) big data, e-science, informatics; (e)

Nursing Outlook, Vol 63, No. 4 (July-August, 2015): pg. 398-407. DOI. This article is @ Elsevier and permission has been granted for this version to appear in e-Publications@Marquette. Elsevier does not grant permission for this article to be further copied/distributed or hosted elsewhere without the express permission from Elsevier. 
quantitative sciences; ( $f$ ) translational science; and ( $g$ ) health economics. Additional nursing scientists with expertise in these content areas were then asked to join the IFAC. The IFAC carried out their work using e-mail, phone conferences, and face-to-face meetings whenever any members attended regional or national meetings over the next 2 years.

\section{Work Groups}

The major work of the IFAC took place in small groups focused on one of the seven emerging and priority areas of science. Each work group was led by an IFAC member who, with the assistance of other IFAC members, identified seasoned and promising new investigators in nursing and related fields from across the country to be invited to participate in the work groups. Work group rosters are listed as Supplementary Data. A standardized template was used by individual members and work group conveners to summarize thoughts, deliberations, and recommendations. Each group summarized the current state of knowledge in the content area, implications for nursing science, and intersections with priority health issues of specific groups and populations across settings and over time. A strengths, weaknesses, opportunities, threats format was used to take stock of the current status of nursing PhD programs for preparing future nursing scientists in each area. Then, implications for program content and training experiences, faculty expertise, and PhD student qualifications for study in each targeted area of science were addressed.

\section{Panel Discussions}

During the 2013/2014 academic year, IFAC members hosted or took part in panel discussions at the annual AACN Doctoral Conference and the annual meetings of the four regional research societies, the Midwest Nursing Research Society, the Eastern Nursing Research Society, the Southern Nursing Research Society, and the Western Institute of Nursing. Background information about the CANS Idea Festival for Nursing Science Education and each emerging area of science were presented, and a variety of formats (e.g., wicked questions, open discussion, and point counterpoint) were used to 
stimulate broader dialogue with other nursing researchers, educators, and doctoral students about the future of nursing science education with regard to these emerging areas of science.

\section{CANS Membership and Boards}

The draft "white paper" composed of the background (Henly et al., 2015) and recommendations (this article) was presented at the 2014 CANS State of the Science Congress. Feedback obtained at the conference was later discussed and incorporated into the papers. The CANS Steering Committee and the Board of Directors of the American Academy of Nursing reviewed the papers and IFAC recommendations about emerging areas of science and the future of nursing science education.

\section{Discussion}

\section{Panels}

Approximately 200 attendees at the AACN, Midwest Nursing Research Society, Eastern Nursing Research Society, Southern Nursing Research Society, and Western Institute of Nursing were present at the panel discussions. Attendees were generally enthusiastic about the importance of discussing the future of PhD education in nursing. It took some effort to keep the conversations focused on program content (emerging and priority areas of science) rather than process (e.g., format for dissertation, face-to-face, or online program delivery). The panel discussions at the regional research society meetings uncovered broader issues for some PhD program faculty that impact the preparation for future nursing scientists including (a) lack of clarity about what constitutes core knowledge needed by all PhD graduates; (b) lack of clarity about the meaning of nursing inquiry, nursing science, and phenomena within the domain of nursing science; (c) growing importance of specialization in content areas, including the question of what might be removed from PhD programs to allow time and resources needed for the development of content specialization or depth; and (d) challenges that data-driven e-science pose regarding the long-standing centrality of theory in nursing research.

Nursing Outlook, Vol 63, No. 4 (July-August, 2015): pg. 398-407. DOI. This article is @ Elsevier and permission has been granted for this version to appear in e-Publications@Marquette. Elsevier does not grant permission for this article to be further copied/distributed or hosted elsewhere without the express permission from Elsevier. 
NOT THE PUBLISHED VERSION; this is the author's final, peer-reviewed manuscript. The published version may be accessed by following the link in the citation at the bottom of the page.

\section{Work Groups}

\section{Knowledge Areas and Nursing Science}

Highlights of work group input are summarized in Table 2. In work group discussions, there was consensus that nursing scientists should be actively involved in research in the emerging areas of science to advance nursing knowledge and nursing practice. Each science area can contribute to the scientific underpinnings of individualized and cost-effective nursing interventions. Omics was seen as widely applicable to nursing science and practice at both behavioral and biological levels, accounting for the union of nature and nurture, with potential to advance understanding of the "symptome" and advance treatment in acute and chronic illness (cf. Grady, 2014). The patient-reported outcomes, informatics, and health economics groups each argued that increased knowledge of the substance and methods in these content areas was needed for new insight and measurement of individualized patient and aggregate outcomes of care that can be verified through quantitative analysis. Knowledge of health economics has not been visible as part of nursing science but is needed to inform health services research and use of big data to better understand the everyday effectiveness of nursing interventions at individual, family, group, or community levels of care.

Table 2. Emerging and Priority Areas of Nursing Science: Strengths, Weaknesses, Opportunities, and Threats for PhD Programs

\begin{tabular}{|c|c|c|}
\hline Area & Characteristic & Highlights \\
\hline \multirow[t]{4}{*}{ Omics/microbiome } & Strengths & $\begin{array}{l}\text {-Applicability to a wide range of areas in nursing } \\
\text { science, with unique ability to "translate" } \\
\text { findings from basic research to human health } \\
\text { problems } \\
\text {-Increasing awareness of the necessity of } \\
\text { incorporating omics into nursing science } \\
\text { leveraged by NINR support }\end{array}$ \\
\hline & Weaknesses & \begin{tabular}{|l}
-Faculty and PhD students lack prerequisite \\
knowledge in biology, chemistry, and omics \\
needed to compete successfully in omics \\
sciences \\
- Laboratory capacity and statistical analysis for \\
genomics data are limited in schools of nursing
\end{tabular} \\
\hline & Opportunities & $\begin{array}{l}\text { - Reformulation of nursing science to fully } \\
\text { incorporate biological approaches } \\
\text {-Potential to advance nursing's visibility and } \\
\text { contributions to health sciences at large }\end{array}$ \\
\hline & Threats & $\begin{array}{l}\text { Rapid advancement of omics fields creates } \\
\text { challenges in maintenance of scientific expertise }\end{array}$ \\
\hline
\end{tabular}

Nursing Outlook, Vol 63, No. 4 (July-August, 2015): pg. 398-407. DOI. This article is @ Elsevier and permission has been granted for this version to appear in e-Publications@Marquette. Elsevier does not grant permission for this article to be further copied/distributed or hosted elsewhere without the express permission from Elsevier. 
NOT THE PUBLISHED VERSION; this is the author's final, peer-reviewed manuscript. The published version may be accessed by following the link in the citation at the bottom of the page.

\begin{tabular}{|c|c|c|}
\hline Area & Characteristic & Highlights \\
\hline & & $\begin{array}{l}\text {-Without action now, other disciplines will } \\
\text { incorporate symptom science, end of life, and } \\
\text { self-management/health behaviors into their } \\
\text { programs of research; nursing will lose the edge } \\
\text { developed in this areas }\end{array}$ \\
\hline \multirow[t]{4}{*}{ PROs } & Strengths & $\begin{array}{l}\text {-Long-standing accomplishments in patient-reported } \\
\text { outcomes research, with accomplishments in } \\
\text { theoretical and conceptual underpinnings, } \\
\text { instrument development, use of qualitative and } \\
\text { mixed methods, and biomarkers } \\
\text {-Growing interest in the use of common data } \\
\text { elements }\end{array}$ \\
\hline & Weaknesses & $\begin{array}{l}\text { - Few PhD programs teach newer measurement } \\
\text { methods such as item response theory } \\
\text {-Few PhD programs teach data processing, data } \\
\text { mining, and management of large data sets }\end{array}$ \\
\hline & Opportunities & $\begin{array}{l}\text {-Advance PROs using nursing science expertise: } \\
\text { qualitative methods, cultural influences on health } \\
\text { measurement } \\
\text {-NIH/NINR emphasis on big data and common data } \\
\text { elements in research }\end{array}$ \\
\hline & Threats & $\begin{array}{l}\text {-"Old" think in terms of psychometrics } \\
\text { - Limited focus on special outcomes and special } \\
\text { populations (e.g., children) }\end{array}$ \\
\hline \multirow[t]{4}{*}{ Health behavior } & Strengths & \begin{tabular}{|l} 
- Health behavior, behavior change, and \\
biobehavioral science is well developed \\
- Research results are relevant to solutions to \\
prevalent, serious health problems
\end{tabular} \\
\hline & Weaknesses & $\begin{array}{l}\text { - Few investigators prepared to incorporate } \\
\text { technology } \\
\text {-New research designs for personalized } \\
\text { interventions not included in PhD programs }\end{array}$ \\
\hline & Opportunities & $\begin{array}{l}\text {-Partnerships with behavioral and social scientists } \\
\text {-New approaches can extend understanding of } \\
\text { behavior and mechanisms of interventions } \\
\text { - Contribute to better understanding of health } \\
\text { trajectories across the life span } \\
\text { - Extend understanding beyond cognitive basis of } \\
\text { behavior to emotional foundations }\end{array}$ \\
\hline & Threats & $\begin{array}{c}\text { Competition from other fields may usurp core } \\
\text { nursing scientific focus in this area }\end{array}$ \\
\hline \multirow[t]{2}{*}{ Big data } & Strengths & $\begin{array}{l}\text {-Big data from many sources-clinical databases, } \\
\text { patient-generated data, and omics-have } \\
\text { potential to inform and advance all areas of } \\
\text { nursing science and practice } \\
\text {-Big data approaches can inform intervention } \\
\text { research, clinical guidelines, and personalization } \\
\text { of nursing care }\end{array}$ \\
\hline & Weaknesses & \begin{tabular}{|c|c|}
-Few existing faculty in nursing PhD programs have \\
expertise needed to teach and mentor students
\end{tabular} \\
\hline
\end{tabular}

Nursing Outlook, Vol 63, No. 4 (July-August, 2015): pg. 398-407. DOI. This article is @ Elsevier and permission has been granted for this version to appear in e-Publications@Marquette. Elsevier does not grant permission for this article to be further copied/distributed or hosted elsewhere without the express permission from Elsevier. 
NOT THE PUBLISHED VERSION; this is the author's final, peer-reviewed manuscript. The published version may be accessed by following the link in the citation at the bottom of the page.

\begin{tabular}{|c|c|c|}
\hline Area & Characteristic & Highlights \\
\hline & & $\begin{array}{l}\text {-Data sharing, use of standardized languages and } \\
\text { common data elements, and data visualization } \\
\text { are not consistently used in nursing science } \\
\end{array}$ \\
\hline & Opportunities & $\begin{array}{l}\text {-NIH Office of Data Science is supporting research } \\
\text { use of clinical data, data standards, training, } \\
\text { simulation, and software development across } \\
\text { multiple disciplines } \\
\text {-Bioinformatics, personalized medicine, and } \\
\text { computational biology provide insight into how } \\
\text { genes, RNA, proteins, metabolites, and many } \\
\text { perspectives in physiology influence effects of } \\
\text { nursing interventions }\end{array}$ \\
\hline & Threats & \begin{tabular}{|l} 
- Few PhD programs teach data science \\
- Failure to adopt data science approaches will make \\
nursing research subpar compared with related \\
disciplines
\end{tabular} \\
\hline \multirow[t]{4}{*}{ Quantitative sciences } & Strengths & $\begin{array}{l}\text { - Statistics as a long-standing core element in the } \\
\text { nursing PhD curriculum }\end{array}$ \\
\hline & Weaknesses & $\begin{array}{l}\text { - Depth and breadth of statistical instruction are } \\
\text { fairly limited } \\
\text { - Few existing faculty have expertise in advanced } \\
\text { methods }\end{array}$ \\
\hline & Opportunities & $\begin{array}{l}\text {-Team science opens opportunities for long-term } \\
\text { collaboration between investigators and } \\
\text { quantitative methodologists } \\
\text {-Increasing importance of data mining, data } \\
\text { visualization, simulation, and computational } \\
\text { biology add to motivation for mastering } \\
\text { mathematical foundations common to all fields of } \\
\text { science (calculus and linear algebra) }\end{array}$ \\
\hline & Threats & $\begin{array}{l}\text {-Widespread innumeracy in the United States; low } \\
\text { expectations for study of mathematics in } \\
\text { baccalaureate nursing programs } \\
\text { - Belief that quantitative aspects of research can be } \\
\text { left to a statistician }\end{array}$ \\
\hline \multirow[t]{4}{*}{ Translation science } & Strengths & $\begin{array}{l}\text {-Long-standing scientific accomplishments and } \\
\text { national leadership by individual nurse scientists } \\
\text {-Clinical expertise }\end{array}$ \\
\hline & Weaknesses & $\begin{array}{l}\text { - Uncertain value for implementation science within } \\
\text { nursing science community } \\
\text { - Lack of interest/commitment to } \\
\text { dissemination/translation of findings among } \\
\text { researchers } \\
\text { - Programs in siloes with little opportunity for } \\
\text { interdisciplinary collaboration }\end{array}$ \\
\hline & Opportunities & $\begin{array}{l}\text { - Leadership in schools/colleges of nursing for } \\
\text { interdisciplinary translation science efforts } \\
\text { - Collaborative projects between PhD and DNP } \\
\text { faculty regarding evaluation of clinical outcomes } \\
\text { and effective implementation methods }\end{array}$ \\
\hline & Threats & $\begin{array}{l}\text { - Lack of federal training grants for translation } \\
\text { science } \\
\text { - Lack of faculty expertise in methods of comparative } \\
\text { effectiveness research methods and } \\
\text { translational/implementation science }\end{array}$ \\
\hline
\end{tabular}

Nursing Outlook, Vol 63, No. 4 (July-August, 2015): pg. 398-407. DOI. This article is @ Elsevier and permission has been granted for this version to appear in e-Publications@Marquette. Elsevier does not grant permission for this article to be further copied/distributed or hosted elsewhere without the express permission from Elsevier. 
NOT THE PUBLISHED VERSION; this is the author's final, peer-reviewed manuscript. The published version may be accessed by following the link in the citation at the bottom of the page.

\begin{tabular}{|c|c|c|}
\hline Area & Characteristic & Highlights \\
\hline \multirow[t]{4}{*}{ Health economics } & Strengths & $\begin{array}{l}\text {-Strong national nursing research portfolio focused } \\
\text { on patient-centered prevention and behavioral } \\
\text { interventions }\end{array}$ \\
\hline & Weaknesses & $\begin{array}{l}\text { - Few programs include health policy courses or } \\
\text { health policy as an area of specialization in } \\
\text { nursing science } \\
\text {-Knowledge about fundamentals of economics and } \\
\text { economics research are rare in nursing } \\
\end{array}$ \\
\hline & Opportunities & $\begin{array}{l}\text { - Contemporary focus on value and prevention in the } \\
\text { health sciences creates openings for a nursing } \\
\text { science leadership role } \\
\text {-Availability of big data to understand and predict } \\
\text { everyday effectiveness of interventions }\end{array}$ \\
\hline & Threats & $\begin{array}{l}\text { - Basic understanding of health economic concepts } \\
\text { and how health care insurance markets, cost } \\
\text { sharing, and health financing policy can affect } \\
\text { costs, charges, health care delivery, and patient } \\
\text { behavior is necessary to ensure implementation } \\
\text { of efficacious nursing interventions }\end{array}$ \\
\hline
\end{tabular}

DNP, doctor of nursing practice; NIH, National Institutes of Health; NINR, National Institute of Nursing Research; PROs, patient-reported outcomes.

Work groups also expressed concern that nursing science and PhD education were not "keeping up" with knowledge and technological advances in the emerging areas of science. This was especially true in the areas of translation science, big data/e-science, and omics. The significant contributions of nursing research to understanding health behaviors, behavior change, and human responses to altered health states were recognized, but the incorporation of contemporary methods (imaging, biomarkers, technology-enhanced data collection/m-health) into nursing research was seen as lagging in most research-focused doctoral programs in nursing. Concerns about the need for more advanced training in quantitative methods, translation science, and health economics cut across all the content areas; quantitative methods and health economics were seen as relevant to nursing research across populations, settings, and over time, with implications for health care outcomes and health systems.

\section{The Recommendations}

In 2005, the National Research Council (NRC) of the American Academies recommended that "research training for nurses, as for other biomedical and behavioral researchers, needs to occur within

Nursing Outlook, Vol 63, No. 4 (July-August, 2015): pg. 398-407. DOI. This article is @ Elsevier and permission has been granted for this version to appear in e-Publications@Marquette. Elsevier does not grant permission for this article to be further copied/distributed or hosted elsewhere without the express permission from Elsevier. 
strong research-intensive universities" with "an interdisciplinary cadre of researchers" and "senior nursing scientists with sustained funding of their programs of research and obvious productivity in terms of publications and presentations" (NRC of the National Academies, 2005, p. 73). Five years later, the AACN (2010) set forth essential program elements needed to prepare PhD graduates to develop the science, steward the profession, and educate new nurse researchers.

As noted in Henly et al. (2015), the proliferation of researchfocused PhD programs in the past 20 years and the limited visibility of emerging areas of science in most PhD program curricula (Wyman \& Henly, 2015) again underscore the need for nursing scientists to consider the content of study in research-focused doctoral programs in nursing. This report specifically targets PhD programs with the resources and faculty expertise to prepare its graduates for careers as nursing scientists in a competitive research climate that often emphasizes biological drivers of health behaviors and health outcomes, big data, translation, and health economics in a team science environment. IFAC recommendations for the incorporation of emerging and priority areas of science into PhD education of nursing scientists address science content, faculty, and students in these programs. These recommendations range from ensuring that all PhD graduates have foundational knowledge in these content areas to providing indepth training in the content and methods needed to launch and sustain a competitive career in an emerging area of nursing science.

\section{Science Content}

\section{Grounding in Nursing Science}

Inculcating a passion for health and health-related phenomena-the core substance of nursing-is central to advancing nursing science (Donaldson, 2003b and Meleis, 1987). Preliminary or comprehensive examinations should be used to ensure that students possess core disciplinary knowledge on health; health behaviors; and optimum health for individuals, families, and communities in context and over time. A full grasp of core nursing knowledge and gaps in knowledge is essential before undertaking dissertation research to explicate root causes of health risk behaviors, to design personalized or tailored interventions to promote, protect or restore health, or to

Nursing Outlook, Vol 63, No. 4 (July-August, 2015): pg. 398-407. DOI. This article is @ Elsevier and permission has been granted for this version to appear in e-Publications@Marquette. Elsevier does not grant permission for this article to be further copied/distributed or hosted elsewhere without the express permission from Elsevier. 
evaluate outcomes of nursing care. Despite the uniformity with which theory, statistics, and research methods are included in nursing PhD programs in the United States (Wyman \& Henly, 2015), these topics in isolation do not constitute core disciplinary knowledge but rather support knowledge development in nursing science. Curriculum and instruction should be designed to integrate theory, quantitative methods, and qualitative methods with the content of nursing science-health and health-related phenomena. Rapid advances in science, technology, and quantitative sciences that impact our ability to conduct relevant and cutting-edge research require students be conversant in these emerging areas of science and understand how they can be used to understand phenomena of concern to nursing as a discipline.

PhD students aspiring to competitive research careers need breadth of exposure to emerging areas of science and methodologies to be able to read, critically appraise, and use new knowledge in their own research. Foundational knowledge in biology, physical sciences, behavioral sciences, and quantitative sciences on par with all the health sciences is critical. Workshops or course work (overview or survey courses/seminars) should be available to ensure that students have a working scientific knowledge base in these areas. Interinstitutional collaborations across nursing PhD programs like the NEXus Collaborative (http://www.winnexus.org/) or the CourseShare or Traveling Scholar programs of the Committee on Institutional Collaboration (http://www.cic.net/projects/shared-courses) may be a fruitful and cost-effective way to ensure that students obtain broad grounding in emerging areas of science relevant to the development of nursing science and the advancement of nursing practice; programs should develop, identify, and communicate collaborative arrangements that support this outcome.

\section{Identify Areas of Specialization}

Research-focused PhD programs should not be "generic" in content. Variation in areas of specialization among programs should be encouraged and expected because no one program could possibly have the resources to provide students with competitive expertise in all areas of science relevant to nursing. Clear identification and communication of available areas of PhD study are essential for the

Nursing Outlook, Vol 63, No. 4 (July-August, 2015): pg. 398-407. DOI. This article is (C) Elsevier and permission has been granted for this version to appear in e-Publications@Marquette. Elsevier does not grant permission for this article to be further copied/distributed or hosted elsewhere without the express permission from Elsevier. 
recruitment of students and faculty and for garnering extramural funds for doctoral training. Programs should name areas of specialization, provide information about faculty expertise and funded research, describe opportunities for mastery of research methods in the areas of specialization, and outline prerequisite knowledge or course work needed by students wishing to pursue study in the available areas of specialization.

The following current areas of specialization in nursing science reflect past accomplishments and research priorities supported by the NINR (n.d.): symptom science and personalized heath strategies; quality of life, symptom management, self-management, and chronicity; end-of-life care, palliative care, and the science of compassion; and wellness, health promotion, and disease prevention. However, identified areas of program specialization should also reflect the scientific approaches and methods training opportunities in the program, such as omics/biomolecular, biobehavioral, bioinformatics, and health economics. Specialties should be "named" at a level of granularity that communicates program emphasis and allows nimble refocusing of emphasis as knowledge in the field develops and advances.

\section{Interdisciplinary Collaboration}

Interdisciplinary collaboration is essential to support specialized training in the content and methods of emerging and priority areas in science and ensuring that students are trained in accordance with related standards in their specialized area of inquiry. Interdisciplinary collaborations are also essential to training in team science. The NINR Centers of Excellence program endorsed the formation and operation of cross-disciplinary teams to accelerate progress in a focused area of health science (Dorsey et al., 2014). Co-location of center researchers was encouraged to promote cross-fertilization of ideas, sharing of resources, and the development of scientists in the center's focused area of science. Collaboratories (Lee, McDonald, Anderson, \& TarczyHornoch, 2009) housed in schools/colleges of nursing should be developed to support nursing research and advance nursing science while providing students and faculty authentic engagement with scientists from related disciplines.

Nursing Outlook, Vol 63, No. 4 (July-August, 2015): pg. 398-407. DOI. This article is @ Elsevier and permission has been granted for this version to appear in e-Publications@Marquette. Elsevier does not grant permission for this article to be further copied/distributed or hosted elsewhere without the express permission from Elsevier. 
NOT THE PUBLISHED VERSION; this is the author's final, peer-reviewed manuscript. The published version may be accessed by following the link in the citation at the bottom of the page.

\section{Research Experience}

Research practica or immersion experiences must be incorporated into all programs that advertise the preparation of $\mathrm{PhD}$ students for competitive careers in nursing science. The practica should integrate relevant laboratory or field research methods, statistical analysis, and content application in target populations. General research experience is not adequate. For example, students specializing in the application of omics or the microbiome for nursing science need practica in laboratory settings; students specializing in translation research need to work with teams of experienced implementation investigators at points of care (health care settings, homes, and schools); and students specializing in predictive analytics need experience with discovering knowledge in large data sets or simulating complex systems as part of an iterative process of theory development and model building (cf. Founds, 2009). Students specializing in health information technologies such as $m$-health to promote behavior change must have opportunities to be involved on research teams developing and testing emerging technologies that can be used for behavioral assessment and intervention. Practical training experiences are best leveraged when performed in collaboration with the advisor/mentor research and ongoing faculty research and dissemination activities.

\section{Faculty}

Meaningful experiences and interactions with experts in nursing science and related fields are essential to providing PhD students with depth in an emerging area of science relevant to increasing the knowledge for nursing practice. To keep pace with advances relevant to the science of nursing, faculty will require funding or other organizational supports that provide opportunities to "retool"-to develop needed expertise in emerging areas of science through course work, workshops, postdoctoral study, career development awards, or sabbaticals in collaboration with seasoned investigators in the area of interest. The National Institutes of Health (NIH) sponsors research training opportunities such as the Summer Genetics Institute and Big Data in Symptoms Research Boot Camp. Professional societies often offer workshops on novel research methods and scientific updates in a

Nursing Outlook, Vol 63, No. 4 (July-August, 2015): pg. 398-407. DOI. This article is (C Elsevier and permission has been granted for this version to appear in e-Publications@Marquette. Elsevier does not grant permission for this article to be further copied/distributed or hosted elsewhere without the express permission from Elsevier. 
specialized area of research. For example, CANS State of the Science and Special Topics conferences emphasize developments in emerging areas of science and showcase their use to advance nursing science and inform research in related fields.

PhD programs preparing graduates in an emerging area of nursing science should provide faculty appointments for scientists educated in the relevant fields (such as omics, informatics and analytics, biologically based psychology/neuroscience, or health economics) who are committed to advancing the health of individuals, families, and communities. Identified areas of program specialization can be used for recruitment of promising new investigators to provide a mix of faculty with related expertise or breadth of expertise in the field such as informatics, where expertise can range from machine learning to integration of biomedical data. Collaborative or interdisciplinary models of teaching and research are needed to support NIH pre- and postdoctoral training awards and awards from the NINR Centers of Excellence program. Interdisciplinary faculty models also increase training and research opportunities for PhD students and nursing scientists within research consortia funded by NIH Clinical and Translational Science Awards. Finally, scientists with research degrees in related fields may find the potential for uptake and application of findings from their work to be a significant motivator for seeking and accepting tenure track appointments in schools or colleges of nursing.

\section{Students}

\section{Prerequisite Knowledge}

The cadre of future nursing scientists will continue to arise from students with prior degrees in nursing but will also include students with prior degrees in biology, chemistry, psychology, informatics, engineering, and other fields related to nursing science. Undergraduate nursing students planning careers in nursing science will need to complete courses in calculus, biology, chemistry, data science, and physics as do undergraduate students in the biosciences, computer sciences, and bioengineering. Faculty must pay greater attention to evaluating quantitative skills of students before accepting them into PhD programs of study. Additional options to facilitate

Nursing Outlook, Vol 63, No. 4 (July-August, 2015): pg. 398-407. DOI. This article is @ Elsevier and permission has been granted for this version to appear in e-Publications@Marquette. Elsevier does not grant permission for this article to be further copied/distributed or hosted elsewhere without the express permission from Elsevier. 
student success in a research-intensive doctoral program include prerequisite course work or "boot camps" in statistics or biological sciences such as omics.

Nursing as a discipline must increase efforts to enhance the popular image of nurses (Price \& Hall, 2013); accurate and widely disseminated portrayals of nursing scientists may be critical to attracting science and technology-oriented high school students to undergraduate programs in nursing. Alternatively, undergraduate programs in nursing can require applicants to have taken calculus, physics, chemistry, and biological science in high school or before admission to the nursing major. Graduate students who do not have a prior degree in nursing are often required to complete additional course work in disciplinary knowledge for nursing practice. However, as noted by the NRC (2005), it is time for PhD programs in nursing to rethink the preparation of nursing scientists who do not intend to enter practice or assume faculty roles in undergraduate or advanced practice programs in nursing for which licensure as a registered nurse is required. PhD programs should be able to prepare nursing scientists with the skills and knowledge needed to advance the science for nursing practice without requiring experience in clinical practice, much like PhD-prepared faculty in the basic science departments in schools of medicine.

\section{Match}

Determining a PhD student's career aspirations and evaluating the match with faculty expertise and specialty areas of study are critical. For programs aiming to prepare its graduates for a competitive career in nursing science, it is also important to assess and admit students who are willing to take full advantage of the opportunities and resources required for training in their targeted area of study. Because many areas of specialization are fast emerging, it should be anticipated that most students will need to fill some gaps in their past education; resources to fill them should be made available by programs and used as needed by individual students. Students enrolled in PhD programs emphasizing emerging areas of science should be counseled throughout their predoctoral training to seek additional or postdoctoral training and to select their first position

Nursing Outlook, Vol 63, No. 4 (July-August, 2015): pg. 398-407. DOI. This article is (C) Elsevier and permission has been granted for this version to appear in e-Publications@Marquette. Elsevier does not grant permission for this article to be further copied/distributed or hosted elsewhere without the express permission from Elsevier. 
NOT THE PUBLISHED VERSION; this is the author's final, peer-reviewed manuscript. The published version may be accessed by following the link in the citation at the bottom of the page.

based on the resources, colleagues, and environment needed to support and advance their program of research.

\section{Next Steps}

The CANS Idea Festival for Nursing Science Education was charged with taking stock of emerging and priority areas of science, considering the implications of these areas for the preparation of PhD students for successful careers as nursing scientists and making recommendations for the incorporation of emerging areas of science into PhD programs in nursing. After 2 years of work and dialogue with PhD faculty and nursing scientists across the country, the IFAC concluded all graduates of research-focused doctoral programs in nursing must possess core nursing knowledge as well as foundational knowledge in emerging areas of science relevant to advancing nursing science and nursing practice. PhD curriculum committees of each school or college of nursing must carefully consider if they wish to prepare graduates with expertise in an emerging area of nursing science and, if they do, to identify and clearly communicate the specialized areas of study available in their PhD program and the prerequisite knowledge required of applicants to their program. Recognizing the commitment that students make in pursuing PhD education, schools and colleges announcing areas of specialization should ensure the availability of faculty expertise and institutional resources needed to support students to launch and sustain scientific careers in their chosen areas of study.

Other tough questions remain to be addressed, and solid answers are needed to ensure that the social mandate for nursing research and practice is met. Among these are the following:

- In light of the need for greater numbers of doctorally prepared nursing faculty, should all programs aim to prepare its graduates for competitive careers as nursing scientists? How does (or should) the preparation of faculty scholars who serve primarily as teachers of the next generation of practicing nurses differ from the preparation of competitive nursing scientists ( Beckett, 2014)?

- What are the implications for hiring and promoting nurse faculty in academic settings with robust tenure requirements for research productivity? What are the implications for hiring non-

Nursing Outlook, Vol 63, No. 4 (July-August, 2015): pg. 398-407. DOI. This article is @ Elsevier and permission has been granted for this version to appear in e-Publications@Marquette. Elsevier does not grant permission for this article to be further copied/distributed or hosted elsewhere without the express permission from Elsevier. 
nurse faculty in colleges and schools of nursing that must maintain disciplinary accreditation for preparation of the next generation of practicing nurses.

- It is generally accepted that other ways of knowing-ethics, aesthetics, and personal-create critical components of disciplinary knowledge in nursing (Carper, 1978). PhD programs aimed at preparing students for scholarly work more akin to the arts and humanities, including history, are implied and may be needed. Should training in science serve as a template for all PhD programs in the discipline? If not, are nursing scientists stewards of the science or stewards of the discipline (cf. AACN, 2010)?

- What content and experiences should be included in the PhD program, and what is better reserved for postdoctoral study? For example, can a PhD student obtain meaningful experience in team science? Encouraging the new NIH K99/R00 "Pathways to Independence" program that links postdoctoral support with transitions to stable independent research positions may be a more realistic model for launching an independent competitive career in nursing science (http://grants.nih.gov/grants/guide/pa-files/PA-14-042.html).

- What is the place of nursing theory in the emerging areas of nursing science? Theory has been critical to the development of nursing as a discipline of study but is infrequently used to frame research problems (Yarcheski \& Mahon, 2013). Nevertheless, virtually all PhD programs today require that students study theory, and some programs place theory and theory development at the center of their program. How can new insights arising from idiographic theory and new research designs for designing and evaluating person-centered and personalized interventions be used to advance nursing science? Relatively atheoretical e-science approaches, aimed at discovery rather than explanation, may be challenging to fit into theorybased PhD programs in nursing. The related data, information, knowledge, wisdom perspective in informatics (Nelson \& Staggers, 2014), with an emphasis on generation of actionable knowledge for decision support, may create the conditions for renewed development of prescriptive theory.

- How can a focus on core knowledge in nursing science be maintained in light of the specialization that is critical to successful scientific careers? Nursing scientists across all areas of specialization must communicate with each other to leverage their efforts and create a cohesive "whole" of nursing science.

- There is a common belief that PhD students in nursing are place bound, choosing doctoral programs because they are accessible

Nursing Outlook, Vol 63, No. 4 (July-August, 2015): pg. 398-407. DOI. This article is @ Elsevier and permission has been granted for this version to appear in e-Publications@Marquette. Elsevier does not grant permission for this article to be further copied/distributed or hosted elsewhere without the express permission from Elsevier. 
or local. If programs identify areas of specialization, will they be able to recruit and support students willing to relocate to pursue their education interests and goals? Can interinstitutional models be harnessed to support training of place-bound students in ways that provide meaningful research practica and interactions with scientists in their area of specialization?

- Academicians in nursing have long argued for the unique contribution of the nursing perspective. Can this unique contribution be articulated and effectively communicated to scientists in related fields, so their work can be enriched by nursing science?

- Is the discipline ready to move from preparing nurses to do science to preparing qualified students to do nursing science irrespective of their prior degrees?

\section{Looking Back, Moving Forward}

Early in the 1980s, the American Academy of Nursing Advisory Group on Knowledge Development and Utilization commissioned a forum to consider the nature of nursing science, theory development, and professional practice as part of setting the American Academy of Nursing agenda for the year 2000. The incisive and forward-thinking report of nearly 30 years ago (Stevenson \& Woods, 1986) described the status of nursing science during the heady years that saw establishment of the National Center/Institute of Nursing Research at the NIH. The expansion of PhD programs in nursing reflected optimism for the future of our young scientific discipline. At that time, the value for holism was recognized as central to directions for research in the new millennium, even as specialization was recognized as essential to scientific progress. Ten years ago, the NRC of the National Academies (2005, p. 74) challenged nursing to "reengineer some of its doctoral programs to exclusively meet the goals of producing scientists . . . in terms of skills and projected career life, to meet the needs of nursing as a science and for development of its research-based disciplinary knowledge." Today's emerging and priority areas of science afford unprecedented opportunities to create truly integrated biopsychosocial, person-centered nursing science that supports attainment of optimal health for all. Structuring PhD programs in nursing to support the aspirations of students for lifelong competitive careers in nursing science is central to reaching this goal.

Nursing Outlook, Vol 63, No. 4 (July-August, 2015): pg. 398-407. DOI. This article is @ Elsevier and permission has been granted for this version to appear in e-Publications@Marquette. Elsevier does not grant permission for this article to be further copied/distributed or hosted elsewhere without the express permission from Elsevier. 
NOT THE PUBLISHED VERSION; this is the author's final, peer-reviewed manuscript. The published version may be accessed by following the link in the citation at the bottom of the page.

\section{Acknowledgments}

Yvonne Bryan, PhD, served as the NINR Liaison for this work. Laura Smothers, MPA, Manager, Council for the Advancement of Nursing Science provided logistical and advisory support. The University of Minnesota School of Nursing, Public Health and Systems Co-operative Unit, provided phone conferencing for IFAC. Contributions of the many nursing scientists, faculty, deans and PhD directors, and students who participated in Idea Festival discussions are acknowledged with appreciation.

\section{References}

American Association of Colleges of Nursing, 2010. American Association of Colleges of Nursing (AACN). The research-focused doctoral program in nursing. Pathways to excellence. (2010) Retrieved from http://www.aacn.nche.edu/education-resources/phdposition.pdf

American Association of Colleges of Nursing, 2006. American Association of Colleges of Nursing (AACN). Nursing research. (2006) Retrieved from http://www.aacn.nche.edu/publications/position/nursing-research

Beckett, 2014. D.O. Beckett. PhD preparation of nurse faculty and nurse scientists: Do they have to be the same? [invited commentary]. Nursing Research, 63 (2014), pp. 156-157

Begg et al., 2014. M.D. Begg, G. Crumley, A.M. Fair, C.A. Martina, W.T. McCarmack, C. Merchant, J.G. Umans, et al. Approaches to preparing young scholars in interdisciplinary team science. Journal of Investigative Medicine, 62 (2014), pp. 14-25

Bennett and Gadlin, 2012. L.M. Bennett, H. Gadlin. Collaboration and team science: From theory to practice. Journal of Investigative Medicine, 60 (2012), pp. 768-775

Carper, 1978. B.A. Carper. Fundamental patterns of knowing in nursing. Advances in Nursing Science, 1 (1) (1978), pp. 13-24

Diez-Roux, 2007. A.V. Diez-Roux. Integrating social and biological factors in health research: A systems view. Annals of Epidemiology, 17 (2007), pp. 569-574

Donaldson and Crowley, 1978. S.K. Donaldson, D.M. Crowley. The discipline of nursing. Nursing Outlook, 26 (1978), pp. 113-120

Donaldson, 2003b. S.K. Donaldson. It's about health, not nursing. [commentary] Journal of Professional Nursing, 19 (2003), pp. 180181

Donaldson, 2003a. S.K. Donaldson. The science of human health-Domain structure and future vision [commentary]. Biological Research for Nursing, 4 (2003), pp. 165-169

Dorsey et al., 2014. S.G. Dorsey, R. Schiffman, N.S. Redeker, M. Heitkemper, D.J. McCloskey, L.S. Weglicki, the NINR Center Directors, et al. National Institute of Nursing Research Centers of Excellence: A model

Nursing Outlook, Vol 63, No. 4 (July-August, 2015): pg. 398-407. DOI. This article is @ Elsevier and permission has been granted for this version to appear in e-Publications@Marquette. Elsevier does not grant permission for this article to be further copied/distributed or hosted elsewhere without the express permission from Elsevier. 
for sustainability, leveraging resources and collaboration to accelerate cross-disciplinary science. Nursing Outlook, 62 (2014), pp. 384-393

Founds, 2009. S.A. Founds. Introducing systems biology for nursing science. Biological Research for Nursing, 11 (2009), pp. 73-80

Glass and McAtee, 2006. T.A. Glass, M.J. McAtee. Behavioral science at the crossroads in public health: Extending horizons, envisioning the future. Social Science \& Medicine, 62 (2006), pp. 1650-1671

Grady, 2014. P. Grady. Welcome. summer genetics institute. National Institutes of Health, Bethesda, MD (2014) Retrieved from https://www.ninr.nih.gov/newsandinformation/newsandnotes/sgiconcludes-2014\#.U_-XGfldUgU

Grey and Mitchell, 2008. M. Grey, P.H. Mitchell. Guest editorial: Nursing and interdisciplinary research. Nursing Outlook, 56 (2008), pp. 95-96

Henly, 2013. S.J. Henly. PhD education in nursing. Changing times, time for reflection. [editorial] Nursing Research, 62 (2013), p. 293

Henly et al., 2015. S.J. Henly, D.O. McCarthy, J.F. Wyman, P.W. Stone, N.S. Redeker, McCarthy, Y.P. Conley, et al. Integrating emerging areas of nursing science into PhD programs. Nursing Outlook, 63 (4) (2015), pp. 408-416

Kneipp et al., 2014. S.M. Kneipp, D. Gilleskie, A. Sheely, T. Schwartz, R.B. Gilmore, D. Atkinson. Nurse scientists overcoming challenges to lead interdisciplinary research teams. Nursing Outlook, 62 (2014), pp. 352361

Lee et al., 2009. E.S. Lee, D.W. McDonald, N. Anderson, P. Tarczy-Hornoch. Incorporating collaboratory concepts into informatics in support of translational interdisciplinary biomedical research. International Journal of Medical Informatics, 78 (2009), pp. 10-21

Meleis, 1987. A.I. Meleis. ReVisions in knowledge development: A passion for substance. Scholarly Inquiry for Nursing Practice, 1 (1987), pp. 5-19

National Institute of Nursing Research, nd. National Institute of Nursing Research (NINR). (n.d.). Implementing NINR's strategic plan: Key themes. Retrieved from www.ninr.nih.gov/aboutninr/keythemes\#.VCrjovk7tcY.

National Institute of Nursing Research, 2011. National Institute of Nursing Research (NINR). Bringing science to life (NIH Publication \#11-7783). Author, Bethesda, MD (2011)

National Research Council of the National Academies, 2005. National Research Council (NRC) of the National Academies. Advancing the nation's health needs. The National Academies Press, Washington, D.C. (2005)

Nelson and Staggers, 2014. R. Nelson, N. Staggers. Theoretical foundations of health informatics. R. Nelson, N. Staggers (Eds.), Health

Nursing Outlook, Vol 63, No. 4 (July-August, 2015): pg. 398-407. DOI. This article is @ Elsevier and permission has been granted for this version to appear in e-Publications@Marquette. Elsevier does not grant permission for this article to be further copied/distributed or hosted elsewhere without the express permission from Elsevier 
NOT THE PUBLISHED VERSION; this is the author's final, peer-reviewed manuscript. The published version may be accessed by following the link in the citation at the bottom of the page.

informatics. An interprofessional approach, Elsevier Mosby, St. Louis, MO (2014), pp. 18-39

Price and Hall, 2013. S.L. Price, L.M. Hall. The history of nurse imagery and the implications for recruiting: A discussion paper. Journal of Advanced Nursing, 70 (2013), pp. 1502-1509

Stevenson and Woods, 1986. J.S. Stevenson, N.F. Woods. Nursing science and contemporary science: Emerging paradigms. G.E. Sorensen (Ed.), Setting the agenda for the year 2000: Knowledge development in nursing, American Academy of Nursing, Kansas City, MO (1986), pp. 6-20

Wyman and Henly, 2015. J.F. Wyman, S.J. Henly. PhD programs in nursing in the United States: Visibility of American Association of Colleges of Nursing core curricular elements and emerging areas of science. Nursing Outlook, 63 (4) (2015), pp. 390-397

Wyman and Henly, 2011. J.F. Wyman, S.J. Henly. Advancing nursing science through health trajectory research. An introduction. Nursing Research, 60 (Suppl 3) (2011), pp. S1-S4

Yarcheski and Mahon, 2013. A. Yarcheski, N.E. Mahon. Characteristics of quantitative nursing research from 1990-2010. Journal of Nursing Scholarship, 45 (2013), pp. 405-411

Author Note. Susan J. Henly was Chair of the CANS Idea Festival Advisory Committee (IFAC). She and Donna O. McCarthy were the primary writers of the paper. Jean F. Wyman was Chair of the Steering Committee, Council for the Advancement of Nursing Science, and had significant roles in the conception and implementation of the Idea Festival for Nursing Science Education. The order of authors in positions 4-12 was determined at random. All authors met criteria for authorship. IFAC members Jerilyn K. Allen, ScD, RN, FAAN, Johns Hopkins University School of Nursing, Baltimore, MD and Suzanne S. Prevost, PhD, RN, COI, University of Alabama, Capstone College of Nursing, Tuscaloosa, AL were non-author contributors.

Corresponding author: Susan J. Henly, University of Minnesota, School of Nursing, 5-140 WDH, 308 Harvard St. SE, Minneapolis, MN 55455.

Nursing Outlook, Vol 63, No. 4 (July-August, 2015): pg. 398-407. DOI. This article is @ Elsevier and permission has been granted for this version to appear in e-Publications@Marquette. Elsevier does not grant permission for this article to be further copied/distributed or hosted elsewhere without the express permission from Elsevier. 
NOT THE PUBLISHED VERSION; this is the author's final, peer-reviewed manuscript. The published version may be accessed by following the link in the citation at the bottom of the page.

\section{Supplementary data}

Council for the Advancement of Nursing Science, Idea Festival for Nursing Science Education: Workgroup Rosters

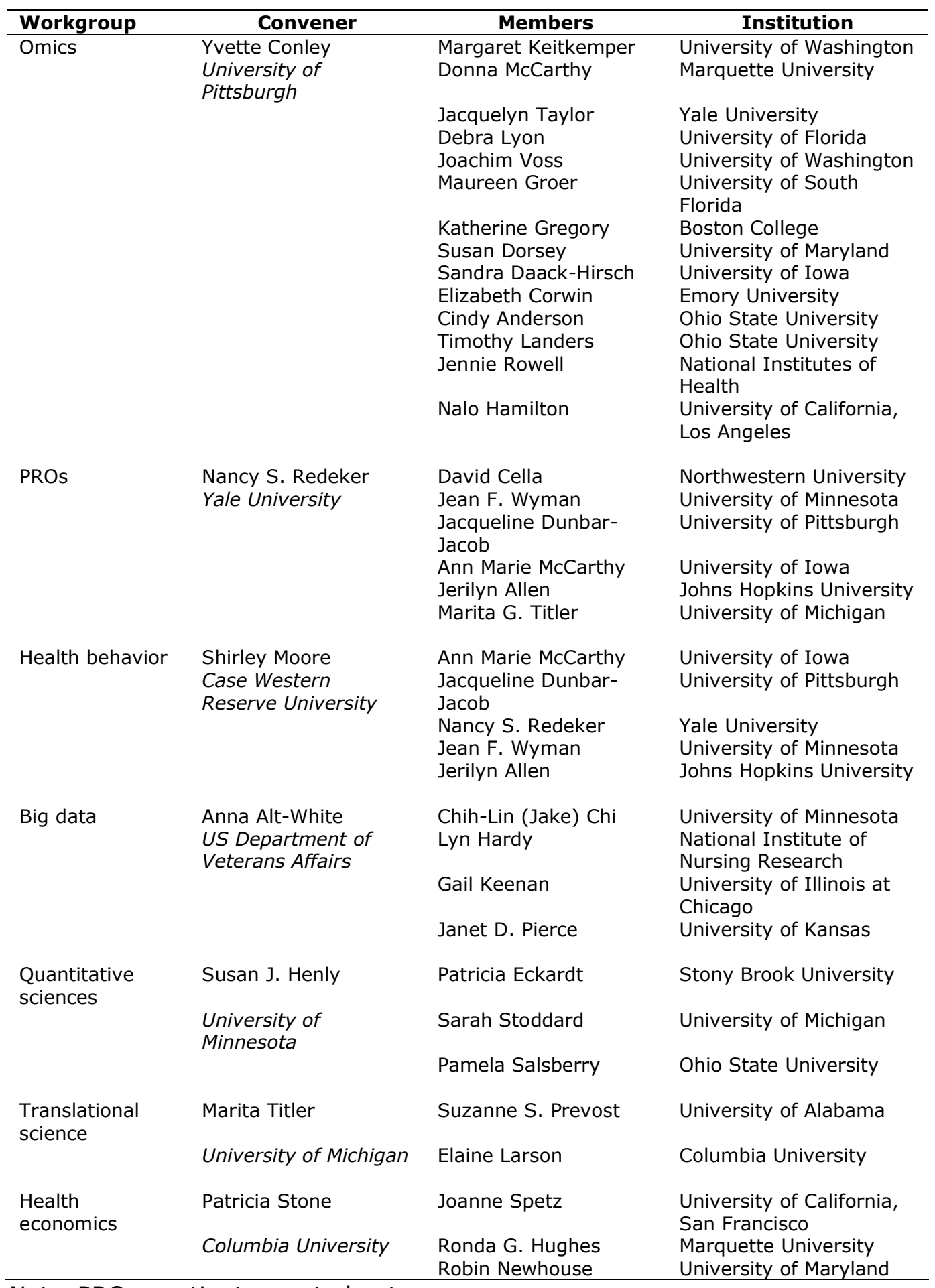

Note. $\mathrm{PRO}=$ patient reported outcome. granted for this version to appear in e-Publications@Marquette. Elsevier does not grant permission for this article to be further copied/distributed or hosted elsewhere without the express permission from Elsevier. 